\title{
Temporal variations in surf zone fish assemblages from False Bay, South Africa
}

\author{
B. M. Clark*, B. A. Bennett, S. J. Lamberth \\ Zoology Department and Marine Biology Research Institute, University of Cape Town, Rondebosch 7700, South Africa
}

\begin{abstract}
Temporal variations in surf zone fish assemblages and various physical factors at 11 sites in False Bay, South Africa, were studied over 2 yr from July 1991 to June 1993. Changes in the abundance of fish in the surf and in the relative ranking of the more frequently occurring species were evident between years and relative to an earlier study. Of the 9 environmental variables monitored, only water temperature and wind direction varied seasonally. Seasonal fluctuations in fish abundance and numbers of species captured were absent, except at 1 site, where numbers of species recorded varied seasonally. Physical factors responsible for these fluctuations varied in response to differences in the physical attributes of the different sites, but water temperature, wave height, wind speed and direction and macrophyte abundance were considered to be the most important. When data from all sites were combined, the overall numbers of fish captured did not appear to vary seasonally. However, seasonal patterns were evident in the abundance of juvenile fish in the surf, and to a lesser extent in the species richness and total number of species captured. Abundance and species richness were highest from mid-summer up to the beginning of winter, which is the penod during which most species recruit into the surf zone. We concluded that even when seasonal varlations in physical variables such as water temperature are not great, spawning periods of surf zone fish are nevertheless timed to allow most resident and transient $0+$ juveniles to optimise their use of this habitat
\end{abstract}

KEY WORDS: Surf zone fish Temporal variability' Environmental influences - Seasonality · Sandy beach South Africa

\section{INTRODUCTION}

Although temporal variations in surf zone fish communities are well documented, much confusion still prevails over the factors influencing or controlling these variations. These have been attributed to fluctuations in a wide variety of both biological and physical variables including the timing of spawning seasons and hence the influx (immigration/recruitment) and efflux (emigration) of individuals to and from populations (e.g. Edwards \& Steele 1968, Jones 1973, Lockwood 1974, Ziljstra et al. 1982, Wright 1988, Gibson et al. 1993), food availability (Lockwood 1974, Creutzenberg et al. 1978, Ross et al. 1987, Lamberth et al. 1995), predation pressure (Riley \& Corlett 1966, Macer 1967. van der Veer \& Bergman 1987, Pihl 1990), water temperature (e.g Warfel \& Merriman 1944, Gunter 1945. Anderson et al. 1977), wind speed and direction (e.g.

·E-mail: bclark@botzoo.uct.ac.za
Modde \& Ross 1981, Lasiak 1982, Pihl 1990, Gibson et al. 1993), turbidity (e.g. Blaber \& Blaber 1980, Ross et al. 1987), salinity (e.g. Gunter 1945, Wright 1988), tidal influences (e.g. Merriman 1947, Edwards \& Steele 1968, Gibson 1973, Modde \& Ross 1981) and time of day (e.g. Lasiak 1984a, Robertson \& Lenanton 1984, Burrows et al. 1994).

All long-term surf zone fish studies have been conducted in temperate and high latitudes, and most have demonstrated the existence of seasonal variations in the abundance and/or species composition of these assemblages (e.g. McFarland 1963, Modde \& Ross 1981, Gibson et al. 1993). Many authors (e.g. Gunter 1958, McFarland 1963, Ross et al. 1987) consider these variations to be the primary characteristic of surf zone fish assemblages. However, few long-term studies, and only 1 of the southern African studies (Lamberth et al. 1995), utilized data collected over a period exceeding 1 annual cycle. Little is thus known of the importance of interannual variations in surf zone fish com- 
munities. Comparisons between temporal variability at different localities have also been hampered by differences in sampling gear and methodology.

In this study, we examined seasonal and interannual variations in the species composition and abundance of fish communities at 11 separate localities, covering a range of physical conditions, in False Bay, South Africa. This paper serves to document long-term (seasonal and interannual) variations in the composition, abundance and community structure of the surf zone fish assemblage as a whole, and at different sites in the Bay. Using multivariate techniques we provide a detailed analysis of the relative importance of the influence of factors such as water temperature, wind speed and direction, wave exposure and macrophyte abundance on temporal variability in surf zone fish community structure and abundance. Spatial variations in abundance and community structure of these assemblages have been described by Clark et al. (1996).

\section{MATERIALS AND METHODS}

This paper forms a companion to that of Clark et al. (1996, this issue) in that it examines temporal variability in physical and biological data collected during that study. The reader is therefore referred to that work for a detailed description of the study area, study sites, sampling equipment and methodology. Briefly, data for this study were collected from approximately monthly seine net hauls made over a 24 mo period between July 1991 and June 1993 at 11 surf zone localities in False Bay $\left(34^{\circ} 15^{\prime} \mathrm{S}, 18^{\circ} 40^{\prime} \mathrm{E}\right)$, South Africa.

Temporal variations in community structure, physical environmental factors and interactions between these variables were analysed using the CLUSTER, MDS and BIOENV programs on the PRIMER computer package, version 4.0 (Plymouth Marine Laboratory, Plymouth, UK). The influence of physical environmental factors on temporal variations in fish density was examined using multiple stepwise regression analyses (Zar 1984) using the SYSTAT computer package (SYSTAT, Inc., Evanston, IL, USA). Weighted Spearman rank correlation coefficients $\left(\rho_{\mathrm{w}}\right)$ and an adjusted multiple coefficient of determination $\left(\mathrm{r}_{\text {adj }}^{2}\right)$ were used as indices of predictive value for the BIOENV and multiple stepwise regression analyses respectively.

All multivariate analyses were performed using data collected and analysed as stated in Clark et al. (1996), except for wind speed and direction. This variable was transformed from a circular to a linear variable by using the cosine of the angle that the wind made on a set of axes aligned perpendicularly onshore at each site. Using axes aligned in this manner resulted in offshore winds at each site being allocated the greatest values (+1), onshore winds the lowest $(-1)$, while winds with a cross-shore component from either direction received scores between +0.9 and -0.9 . This was deemed to be the optimal solution as it was felt that priority should be given to the relative 'on-' or 'offshoreness' of the wind as the influence of winds blowing parallel to the shore from opposite directions was considered to be similar. As the stretch of shoreline over which the sampling sites were distributed was not linear, when biotic data were combined for all sites, wind direction data was transformed from a circular to a linear variable using the cosines of the angle the wind made on a magnetic compass rose. Using this method, winds blowing directly from the south received a score of +1.0 ; winds from the north, -1.0 ; and those with easterly or westerly components, scores between +0.9 and -0.9 . Species richness, diversity and evenness were estimated using Margalef's index ( $d$; Margalef 1958), Shannon's diversity index $\left(H^{\prime}\right)$ and Pielou's evenness index $(J)$ (Pielou 1969) respectively. For the purposes of this study, seasons were defined as follows: September to November = spring; December to February = summer; March to May = autumn; June to August $=$ winter

\section{RESULTS}

\section{Temporal variations in physical environmental iactors}

Monthly variations in water temperature, wind speed and direction, wave height, surf zone width, turbidity and detached macrophyte detrital abundance averaged over the 11 sites are illustrated in Fig. 1. Seasonal patterns were evident in the fluctuations in water temperature, wind direction and possibly turbidity. Water temperatures were highest during the summer months, peaking $\left(20\right.$ to $\left.22^{\circ} \mathrm{C}\right)$ during December and January. Lower temperatures were recorded during the winter months, with the lowest temperatures (11 to $13^{\circ} \mathrm{C}$ ) occurring in July. When data were grouped by season, the summer (mean $\left.=21.5^{\circ} \mathrm{C}\right)$, spring (mean $=$ $18.2^{\circ} \mathrm{C}$ ) and autumn (mean $=17.1^{\circ} \mathrm{C}$ ) temperatures were significantly greater than those of winter (mean $=$ $13.2^{\circ} \mathrm{C}$ ) (ANOVA: $p<0.05, \mathrm{df}=23, F=16.1$ ). Mean temperature during the study period was $17.5^{\circ} \mathrm{C}$. Winds recorded during the summer of both years, being of variable intensity (0.6 to 19.0 knots), were either southerly or southeasterly. Winds with a northerly component were encountered more frequently (42\% of the time) during autumn and spring but remained primarily of southerly origin. Mean wind 
speed varied from 0 to 10 knots during this period. Northerly and northwesterly winds reached their greatest frequency during winter when their frequency of occurrence $(67 \%$ ) and intensity (2.7 to 7.0 knots) were greater than those of southerly winds $(17 \%, 3.5$ knots). Turbidity of the surf zone waters appeared to fluctuate seasonally during the first year, but not in the second. Winter readings were clearly greater than the other seasons during the first year, but although the same general trend was evident during the second year, the highest turbidity 16.9 FTU, Formazin Turbidity Units) was recorded during midsummer of that year. Mean wave height did not vary greatly, ranging between 0.4 and $1 \mathrm{~m}$. Surf zone width varied between 25 and $350 \mathrm{~m}$, and correlated significantly with wave height $(\mathrm{r}=0.63, \mathrm{p}<0.01)$, but displayed no seasonal trends. The total density of detached aquatic macrophytes in the sampling areas ranged from $<0.001 \mathrm{I} \mathrm{m}^{-2}$ (July and October 1992) to $0.51 \mathrm{~m}^{-2}$ (March 1992) The mean macrophyte abundance during the entire sampling period was $0.11 \mathrm{~m}^{-2}$ with no seasonal trends evident.

\section{Temporal variations in fish composition and abundance}

Considerable variation was evident in the density and number of fish species collected from the surf at each of the 11 sampling stations. Fluctuations in abundance at the various sites were not in phase with one another, nor did peaks in abundance correspond from the first year to the second. Similarly, no consistency was evident when the numbers of species captured per month were compared across sites or when comparisons were made from one year to the next at the individual sites. An exception was Blake's Cove, where the number of species taken between December and June of both years 7 to 13) was greater than the numbers taken during the latter part of both years ( 4 to 7 ).

Even when data from all sites were combined (Fig. 2), no seasonal patterns were evident in the total numbers of individuals captured or in the density of fish in the surf zone. Total monthly catch varied between 707 (July 1992) and 9773 ind. (March 1993), while density ranged between 0.15 (July 1992) and 1.76 ind $\mathrm{m}^{-2}$ (September 1991). Mean monthly catch and mean density of fish in the surf were 2859 ind. and 0.64 ind. $\mathrm{m}^{-2}$ respectively.
A weak seasonal trend was, however, evident in the total number of species captured per month when data for all sites was combined (Fig. 2). Fewest species were captured between July and October 1991 (10 to 15) and between July and December 1992 (10 to 14). Numbers of species were greatest between November 1991 and June 1992 (16 to 20) and between January and June 1993 (16 to 22). Numbers peaked during May 1992 (20 species) and April-May 1993 (22 species). Fluctuations in species richness also exhibited a rough seasonal trend. Lowest values $(\leq 1.8)$ were recorded between July and October 1991 and between July and December 1992, while values were higher (1.9 to 2.3) from November 1991 to June 1992 and from January to June 1993. No seasonality was evident in species diversity $\left(H^{\prime}\right)$ or evenness $(J)$ (Fig. 2). Diversity ranged

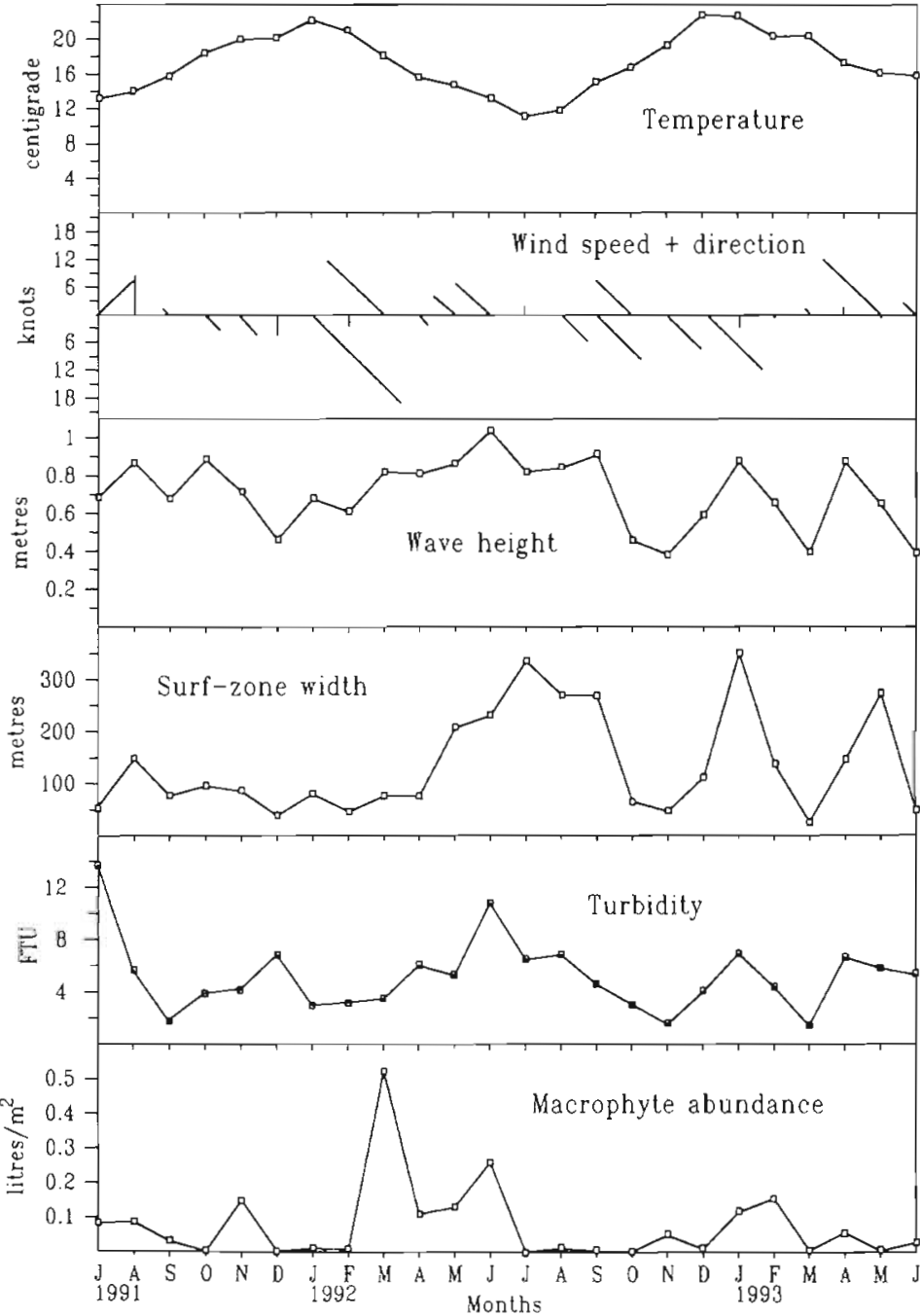

Fig. 1. Monthly variations in mean water temperature $\left({ }^{\circ} \mathrm{C}\right)$, wind speed (knots) and direction, mean wave height $(\mathrm{m})$, mean surf zone width (m), mean turbidity (FTU) and total macrophyte abundance at 11 surf zone localities in False Bay, South Africa, between July 1991 and June 1993 
from 0.553 (September 1991) to 1.615 (January 1993), while evenness ranged from 0.191 (December 1991 , February 1992) to 0.548 (June 1993)

When all fish were divided into adult and juvenile components (Fig. 3a), it was apparent that although peaks in abundance of adult fish did not correspond from one year to the next, a clear seasonal trend was evident in the abundance of juvenile fish in the surf During the first year (July 1991 to June 1992), numbers of juvenile fish were greater (1594 to 3800 , mean = 2500) from January to May than during the remainder of the year (935 to 1744 , mean $=1246$ ). Similarly, catches made between February and June of the second year ( 119 to 5449 , mean $=2667$ ) were considerably greater than during the remaining months (235 to 802 , mean $=662$ ). After the application of a smoothing algorithm ( 3 mo mean) to these data, seasonal trends in

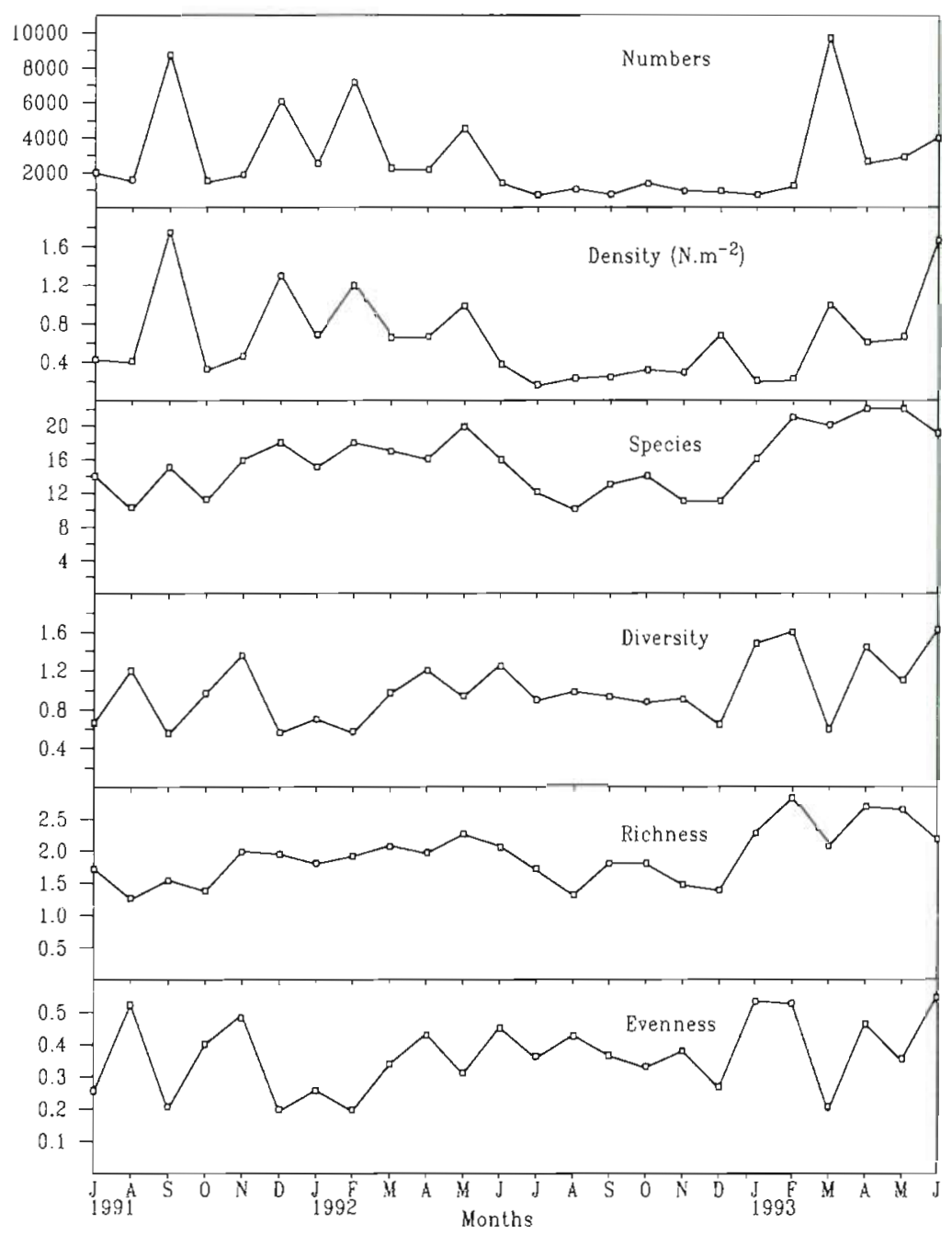

Fig. 2. Monthly variations in the number of individuals, density, number of species, diversity, richness and evenness of surf zone fish in False Bay, between July 1991 and June 1993. Data for all sites combined abundance (Fig. 3b) became even more clear, with peaks occurring in February 1992 and March 1993.

Cluster analysis of the monthly samples (combined sites) separated them into 4 major groups at the $70 \%$ level on the basis of similarities between species composition and abundance (Fig. 4). Groups formed through this analysis showed considerable similarity with respect to the seasonal fluctuations in the number of juvenile fish in the surf, species numbers and richness. Groups 1 and 2 from the cluster analysis (composed of samples collected from July to December 1991 and from June to December 1992) corresponded to periods when juvenile density, species numbers and richness were low, while Groups 3 and 4 (composed of samples collected from January to May 1992 and from January to June 1993) corresponded to periods of high juvenile density, species numbers and richness. This categorisation was borne out by the MDS analysis which separated out the 4 groups of samples identified above, with Groups 1 and 2 appearing on the right hand side of the ordination plot and Groups 3 and 4 appearing on the left hand side of the ordination plot (Fig. 4).

Temporal fluctuations in the total numbers of individuals of each species captured per month (Table 1) separated these species into 3 major groups. The first group comprised 8 'resident' species which were present in the catches more or less throughout the year. This group was made up primarily of the more abundant species, all of which were represented by more than 50 individuals. All but one of these (Rhabdosargus globiceps) were represented by adult and juvenile individuals. The second group of 11 'migrant' species included some (e.g. Lichia amia, Pomatomus saltatrix, Amblyrhynchotes honkenii) which were most abundant during summer and autumn (December to May) and others (e.g. Liza dumerilit, Liza tricuspidens, Mugil cephalus) which were most numerous during autumn and winter (June to November). Most (9) of these species were represented largely, or exclusively, by juveniles. Gilchristella aestuaria, the last species in this category, was more abundant during winter and spring, rarely being present in catches during the rest of the year The final group, termed 'sporadics', contained the greatest number of species (26), almost all of which (25) were represented by 
only a few $(<25)$ individuals. These species were recorded as varying combinations of adult and juvenile fish.

Similarities between patterns in the abundance of the 20 most common species recorded, based on their occurrence in the 24 sampling months, were also examined using Cluster and MDS analysis. Species groupings evident at the $40 \%$ level in the dendrogram (Fig. 5) were also evident in the MDS plot, but were not clearly delineated due to the high stress loading $(0.17)$ on the latter. Groups of species formed by this analysis showed a strong similarity to the categorisation outlined above, in that Groups 1 and 3 (6 and 2 species respectively) were composed solely of 'resident' species, Groups 2 and 4 (4 and 2 species respectively) of 'migrant' species most abundant during summer and autumn, and Group 5 (4 species) of migrant species most abundant during autumn and winter (Fig. 4, Table 1). The 2 remaining species, Sarpa salpa and Gilchristella aestuaria, were not included in any of these groups. The former occurred sporadically in the catches, while the latter was a migrant species most prevalent in the hauls made during winter.

Differences were evident in overall numbers of fish and in population parameters recorded during the first and second years of the study. Both the total number of fish captured (41769) and the mean density $\left(0.763\right.$ fish $\left.\mathrm{m}^{-2}\right)$ during the first year were considerably higher than those recorded during the second year ( 26850 individuals, 0.517 fish $\mathrm{m}^{-2}$ ). However, total number of species recorded during the first year (37) was lower than that recorded during the second (40), with only 30 of the 45 species being recorded in both years. Species richness (3.48), diversity (0.98) and evenness $(0.27)$ were also lower during the first than the second year ( $d=3.82, H^{\prime}=1.39, J=0.38$ ). Decreases in the abundance of the 2 most common species recorded during this study (Atherina breviceps and Liza richardsonil), by 48 and $33 \%$ respectively, were primarily responsible for the decline in numbers and density between the first and second years (Table 1). This trend was not universal, however, as many of the less numerous species (e.g. Diplodus sargus, Pomatomus saltatrix, Heteromycterus capensis, Rhabdosargus globiceps and Umbrina canariensis) showed considerable increases (up to 98-fold) in abundance from the first to the second year. Although no change was evident in the ranking of the top 3 species (A. breviceps, L. richardsonii, $R$. globiceps) from the first year to the second, some changes were evident in

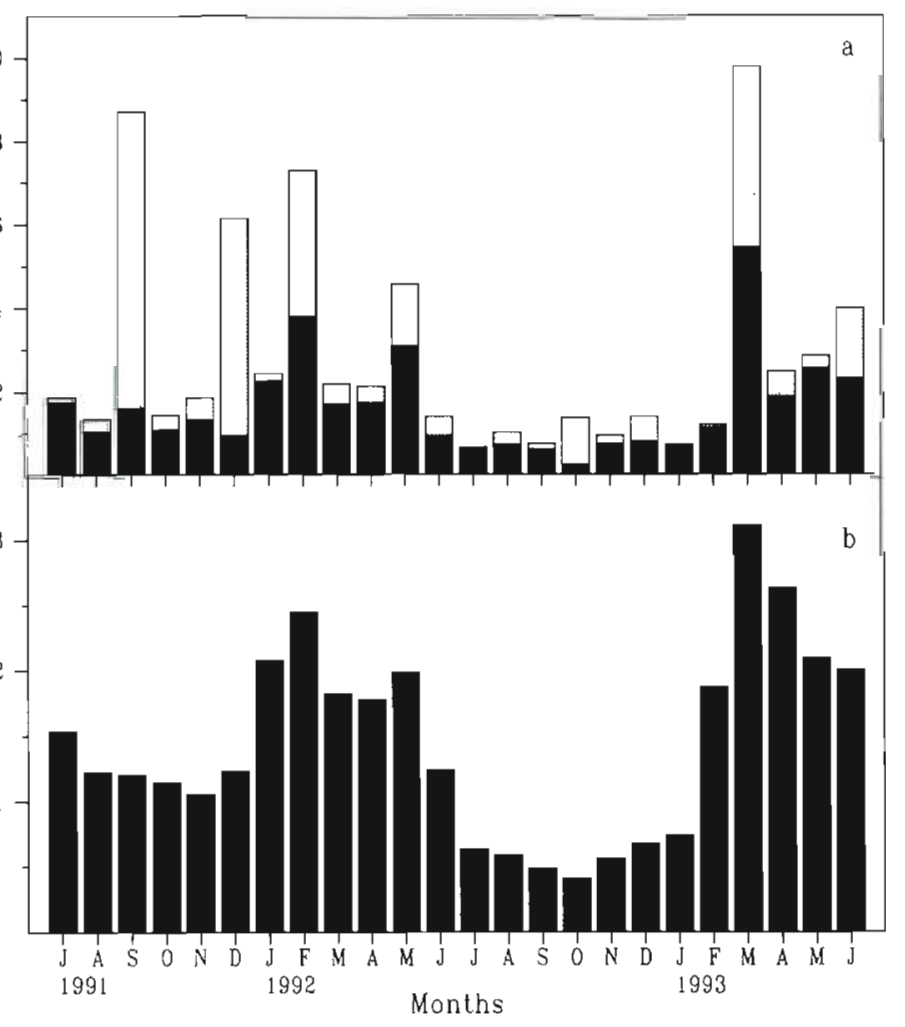

g. 3. Monthly varlations in (a) the number of juvenile (solid bars) and duit fish (stippled bars) and (b) 3 mo mean of juvenile fish abundance in the surf zone of False Bay from July 1991 to June 1993

the relative positions occupied by species in the remaining top 10 places. Some of these (e.g. D. sargus, P. saltatrix, $H$. capensis) increased their relative positions, while others decreased (e.g. Liza tricuspidens, Liza dumerilii, Gilchristella aestuaria) or maintained relatively constant positions (e.g. Psammogobius knysnaensis, Amblyrhynchotes honkenii).

\section{Multivariate analyses of relations between biotic and environmental variables}

Results of the BIOENV and stepwise multiple regression analyses performed on the species composition and the total density data from each of the individual sites are shown in Tables 2 \& 3 respectively. Nine environmental variables (water temperature, wave height, surf zone width, turbidity, wind speed, wind direction, macrophyte detrital abundance, tidal height and time at which the sample was taken) were used in these analyses. Results from the BIOENV procedure yielded rank correlation coefficients $\left(\rho_{w}\right)$ of 0.08 to 0.34 , with the number of environmental correlates for each site ranging between 1 and 6 (Table 2). Wave height $(6$ sites) and water temperature ( 5 sites) were correlated 
with temporal variability in community structure at a greater number of sites than any of the other variables ( 2 or 3 sites only). Results of the stepwise regression analyses indicated that the suite of environmental variables measured have little influence on temporal variations in overall density of fish at the different sites These variables were able to predict $\geq 40 \%$ of the temporal variability at only 3 of the 11 sites, these being Cemetery Beach $\left(r^{2}\right.$ adj. $\left.=0.56\right)$, Sunrise Beach $\left(r^{2}\right.$ adj. $=$
0.51 ) and Melkbaai $\left(\mathrm{r}^{2}{ }_{\mathrm{adj}} .=0.40\right)$ (Table 3). Variables included in these models were wind direction (all 3 sites), wind speed (Sunrise and Melkbaai), time of day (Sunrise only) and temperature and tidal height (Cemetery only). Environmental variables accounted for $<1 \%$ of the fluctuations in overall fish density at the other sites, except for Swartklip, where $16 \%$ of the variability was attributed to variations in surf zone width.

Table 1 Composition and abundance of fish in monthly seine net hauls made in the surf at 11 sites in False Bay, South Africa between July 1991 and June 1993. Fish are classified as being resident (R), migrant (M) or sporadic (S) species, based on their occurrence in the catches. (Table continued across page)

\begin{tabular}{|c|c|c|c|c|c|c|c|c|c|c|c|c|c|}
\hline & Class. & $\begin{array}{r}1991 \\
\text { Jul }\end{array}$ & Aug & Sep & Oct & Nov & Dec & $\begin{array}{r}1992 \\
\text { Jan }\end{array}$ & Feb & Mar & Apr & May & Jun \\
\hline Atherina breviceps & $\mathrm{R}$ & 116 & 320 & 7338 & 310 & 466 & 5147 & 215 & 6269 & 1233 & 433 & 1885 & 580 \\
\hline Liza richardsonil & $\mathrm{R}$ & 1682 & 849 & 1276 & 1006 & 933 & 869 & 2044 & 762 & 827 & 1303 & 2494 & 610 \\
\hline Rhabdosargus globiceps & $\mathrm{R}$ & 11 & 160 & 29 & 69 & 95 & 20 & 74 & 81 & 63 & 324 & 50 & 94 \\
\hline Psammogobius knysnaensis & $\mathrm{R}$ & 14 & 7 & 33 & 41 & 60 & 23 & 25 & 18 & 6 & 12 & 17 & 33 \\
\hline Rhinobatos annulatus & R & 34 & - & 3 & 1 & 6 & 2 & 1 & - & 7 & 2 & 1 & 1 \\
\hline Caffrogobius nudiceps & $R$ & - & 3 & - & - & 5 & 11 & 3 & 1 & 4 & 1. & 7 & - \\
\hline Lithognathus lithognathus & $\mathrm{R}$ & 3 & - & 1 & 1 & 11 & 8 & 5 & 2 & 2 & 6 & 7 & - \\
\hline Clinus superciliosus & $\mathrm{R}$ & 3 & 4 & - & 2 & - & 6 & - & - & 1 & - & 6 & 1 \\
\hline Diplodus sargus & M & 1 & - & - & - & 2 & - & - & - & 2 & - & - & 1 \\
\hline Pomatomus saltatrix & M & - & - & - & - & - & 11 & 38 & 20 & 20 & 1 & 3 & 4 \\
\hline Heteromycteris capensis & M & - & 2 & 22 & 6 & 6 & 1 & 3 & 8 & 1 & 4 & 1 & - \\
\hline Umbrina canariensis & $M$ & 6 & - & 2 & - & - & 1 & - & 1 & - & - & 3 & 4 \\
\hline Lichia amia & M & - & - & - & - & - & 6 & 1 & 1 & 2 & - & - & - \\
\hline Amblyrhynchotes honkenii & M & - & 1 & - & - & 1 & 27 & 25 & 1 & 3 & 2 & - & - \\
\hline Liza tricuspidens & $\mathrm{M}$ & 1 & - & - & 2 & - & - & 1 & 69 & - & 12 & - & 157 \\
\hline Liza dumerilij & M & 4 & 2 & - & - & - & - & - & 50 & - & - & 20 & 7 \\
\hline Mugil cephalus & M & - & - & - & - & - & - & - & 1 & 10 & 1 & 24 & 1 \\
\hline Solea bleekeri & M & - & - & - & - & - & 1 & - & - & 1 & - & 28 & - \\
\hline Gilchristella aestuaria & M & 105 & 160 & 40 & 26 & 5 & 1 & - & 2 & - & 1 & 4 & - \\
\hline Trachinotus africanus & $\mathrm{S}$ & - & - & - & - & - & - & - & - & - & - & - & - \\
\hline Trachinotus botla & $S$ & - & - & - & - & - & - & - & - & - & - & 1 & - \\
\hline Heniochus acuminatus & S & - & - & - & - & - & - & - & - & - & - & - & - \\
\hline Coryphaena hippurus & $\mathrm{S}$ & - & - & - & - & - & - & 3 & - & - & - & - & - \\
\hline Monodactylus falciformes & s & - & - & - & - & - & -- & - & - & - & - & - & - \\
\hline Rhabdosargus holubi & S & - & - & - & - & - & - & - & - & 3 & - & - & 1 \\
\hline Sphyraena acutipinnis & S & - & - & - & - & 1 & - & - & - & - & - & - & - \\
\hline Trachinocephalus myops & S & - & - & - & - & - & - & - & - & - & - & - & - \\
\hline Dichistius multifasciatus & S & - & - & - & - & - & - & - & - & - & 1 & - & - \\
\hline Sarpa salpa & S & - & - & - & - & 271 & - & - & - & - & 29 & 6 & - \\
\hline Caffrogobius caffer & $s$ & - & - & - & - & - & - & - & 1 & - & - & - & - \\
\hline Diplodus cervinus & $\mathrm{S}$ & - & - & - & - & - & - & - & - & - & - & - & - \\
\hline Haploblepharus edwarsii & $\mathrm{S}$ & - & - & - & - & - & - & - & - & - & - & - & - \\
\hline Fucomimus mus & $\mathrm{S}$ & - & - & - & - & - & - & - & - & - & - & - & - \\
\hline Gonorhynchus gonorhynchus & $\mathrm{S}$ & - & - & - & - & - & - & - & - & - & - & - & - \\
\hline Lithognathus mormyrus & $\mathrm{S}$ & - & - & - & $\overrightarrow{-}$ & - & 5 & 5 & - & - & - & - & - \\
\hline Syngnathus acus & $S$ & - & - & - & 1 & - & - & - & - & - & - & - & - \\
\hline Chelidonichthyes capensis & $\mathrm{S}$ & 3 & - & 6 & - & - & - & - & - & - & - & - & 4 \\
\hline Cancelloxus longior & $\mathrm{S}$ & 1 & 2 & 3 & - & 1 & - & - & - & - & - & - & - \\
\hline Trachurus trachurus & $\mathrm{S}$ & - & - & - & - & 1 & - & - & - & - & - & - & - \\
\hline Engraulis japonicus & $\mathrm{S}$ & - & - & - & - & - & 1 & - & - & - & - & - & - \\
\hline Dichistius capensis & $\mathrm{S}$ & - & - & 2 & - & - & - & 2 & 3 & - & 3 & 4 & 1 \\
\hline Clinus latipennis & $\mathrm{S}$ & - & - & 3 & - & 1 & 5 & - & - & 1 & - & 1 & - \\
\hline Triakis megalopterus & $\mathrm{S}$ & - & - & - & - & - & - & - & - & - & - & - & - \\
\hline Dasyatis crysonota & $\mathrm{S}$ & - & - & - & - & - & - & - & - & - & - & 1 & 1 \\
\hline Mydiobatis aquila & S & 1 & - & 4 & - & - & - & - & 1 & - & - & - & - \\
\hline
\end{tabular}


Multivariate analyses involving the grouped data (monthly data from all sites combined) were performed with the same set of physical environmental variables as the above, except that the variables 'time of day' and 'tidal height' were omitted from the models and wind direction was coded in a slightly different manner (see 'Materials and methods'). The BIOENV procedure indicated that of these variables, water temperature alone was responsible for the greatest part of the variability observed $\left(\rho_{w}=0.18\right)$. Stepwise multiple regression analysis suggested that $<20 \%$ of the vari- ability associated with monthly fluctuations in the density of fish in the surf could be predicted by the environmental factors measured, with surf zone width being the only environmental variable selected by the model $\left(\mathrm{r}_{\mathrm{ad} \mathrm{d}}^{2}=0.17\right)$.

\section{DISCUSSION}

Ross et al. (1987) advocated that temporal variations in surf zone fish assemblages and the factors that con-

Table 1 (continued)

\begin{tabular}{|c|c|c|c|c|c|c|c|c|c|c|c|c|c|}
\hline & $\begin{array}{r}1992 \\
\text { Jul }\end{array}$ & Aug & Sep & Oct & Nov & Dec & $\begin{array}{r}1993 \\
\text { Jan }\end{array}$ & Feb & Mar & Apr & May & Jun & Total \\
\hline Atherina breviceps & 67 & 282 & 61 & 1078 & 142 & 23 & 13 & 51 & 8480 & 717 & 257 & 1540 & 37023 \\
\hline Liza richardsonii & 546 & 690 & 563 & 93 & 692 & 815 & 387 & 652 & 763 & 1264 & 2093 & 1261 & 24474 \\
\hline Rhabdosargus globiceps & 19 & 19 & 27 & 133 & 22 & 9 & 58 & 235 & 188 & 122 & 206 & 533 & 2641 \\
\hline Psammogobius knysnaensis & 14 & 13 & 69 & 34 & 51 & 19 & 2 & 27 & 26 & 10 & 2 & 44 & 600 \\
\hline Rhinobatos annulatus & - & - & - & 2 & - & - & 10 & 30 & 56 & 242 & 139 & 210 & 696 \\
\hline Caffrogobius nudiceps & 1 & 2 & - & 3 & 13 & 20 & 71 & 34 & 158 & 21 & 22 & 140 & 582 \\
\hline Lithoganthus lithognathus & - & - & 1 & - & - & 2 & - & 35 & 40 & 3 & 36 & 147 & 324 \\
\hline Clinus superciliosus & 1 & - & - & 2 & 1 & - & 4 & 10 & 14 & 27 & 9 & 8 & 93 \\
\hline Diplodus sargus & 1 & 2 & 1 & 5 & - & - & - & 4 & - & 3 & - & 20 & 91 \\
\hline Pomatomus saltatrix & - & - & 11 & 1 & 5 & 2 & 4 & 2 & 3 & 1. & - & 18 & 82 \\
\hline Heteromycteris capensis & 1 & 2 & - & - & - & 4 & 2 & 1 & - & 7 & - & 5 & 62 \\
\hline Umbrina canariensis & 2 & 1 & 1 & - & 1 & - & 1 & 1 & 3 & 1 & 6 & 18 & 58 \\
\hline Lichia amia & - & - & - & 1 & - & 4 & 5 & 8 & 14 & 3 & - & - & 45 \\
\hline Amblyrhynchotes honkenii & - & - & 1 & 9 & - & 2 & 23 & 80 & 19 & 13 & 6 & 7 & 220 \\
\hline Liza tricuspidens & 52 & 69 & 4 & 21 & - & - & - & 17 & - & - & 9 & 5 & 674 \\
\hline Liza dumerilii & 3 & - & 1 & - & - & - & - & 8 & 1 & 2 & 9 & 1 & 137 \\
\hline Mugil cephalus & 2 & - & - & - & - & - & - & - & - & 7 & 7 & - & 97 \\
\hline Solea bleekeri & - & 1 & 2 & - & - & - & - & - & - & 5 & 18 & - & 66 \\
\hline Gilchristella aestuaria & - & - & - & - & 5 & - & - & 4 & 1 & 1 & 4 & 9 & 30 \\
\hline Trachinotus africanus & - & - & - & - & - & - & - & - & 1 & - & - & - & 1 \\
\hline Trachinotus botla & - & - & - & - & - & - & - & - & - & - & - & - & 1 \\
\hline Heniochus acuminatus & - & - & - & - & - & - & - & 1 & - & - & - & - & 1 \\
\hline Coryphaena hippurus & - & - & - & - & - & - & - & - & - & - & - & - & 3 \\
\hline Monodactylus falciformes & - & - & - & - & - & - & - & - & - & 1 & - & - & 1 \\
\hline Rhabdosargus holubi & - & - & - & - & - & - & 1 & - & - & 2 & 1 & - & 8 \\
\hline Sphyraena acutipinnis & - & - & - & - & - & - & - & - & - & - & - & - & 1 \\
\hline Trachinocephalus myops & - & - & - & - & - & - & - & - & 2 & - & - & - & 2 \\
\hline Dichistius multifasciatus & - & - & - & - & - & - & - & - & - & - & - & - & 1 \\
\hline Sarpa salpa & - & - & - & - & - & - & 134 & - & - & 30 & 17 & - & 488 \\
\hline Caffrogobius caffer & - & - & - & - & - & - & - & - & - & - & 1 & 2 & 4 \\
\hline Diplodus cervinus & - & - & - & - & - & - & - & - & - & - & - & 2 & 2 \\
\hline Haploblepharus edwarsii & - & - & - & - & - & - & - & - & - & - & 1 & - & 1 \\
\hline Fucomimus mus & - & - & - & - & - & - & - & - & - & - & 1 & - & 1 \\
\hline Gonorhynchus gonorhynchus & - & - & - & - & - & - & - & - & 1 & - & - & - & 1 \\
\hline Lithoganthus mormyrus & - & - & - & 1 & 2 & -- & 1 & - & 1 & - & - & - & 15 \\
\hline Syngnathus acus & - & - & -- & - & - & - & - & 1 & - & - & - & - & 2 \\
\hline Chelidonichthyes capensis & - & - & 3 & - & - & - & - & - & 1 & - & 4 & 3 & 24 \\
\hline Cancelloxus longior & - & - & - & - & 1 & - & - & - & 1 & - & - & - & 9 \\
\hline Trachurus trachurus & - & - & - & - & - & -- & - & - & - & - & - & - & 1 \\
\hline Engraulis japonicus & - & - & - & - & - & - & - & - & - & - & - & - & 1 \\
\hline Dichistius capensis & - & - & - & - & - & - & - & - & - & - & - & - & 15 \\
\hline Clinus latipennis & - & - & - & - & - & - & - & 2 & - & - & - & - & 13 \\
\hline Triakis megalopterus & - & - & - & - & - & - & - & - & - & - & 1 & - & 1 \\
\hline Dasyatis crysonota & - & - & - & 1 & - & - & - & - & - & - & - & - & 3 \\
\hline Myliobatis aquila & - & - & - & - & - & - & - & 1 & - & - & - & - & 7 \\
\hline
\end{tabular}


trol these variations could be visualized as a hierarchy, ranging from climatic events that influence annual variations in year class strength, through. reproductive and feeding movements that result in seasonal patterns of occurrence and abundance, to short-term fluctuations in physico-chemical factors such as wave height, salinity, temperature and wind speed that influence point abundance. In this study, the difference between the number of species caught in the first and second years of sampling was not great ( 37 and 40 species respectively). However, the overall numbers of fish caught and the mean density of fish in the surf

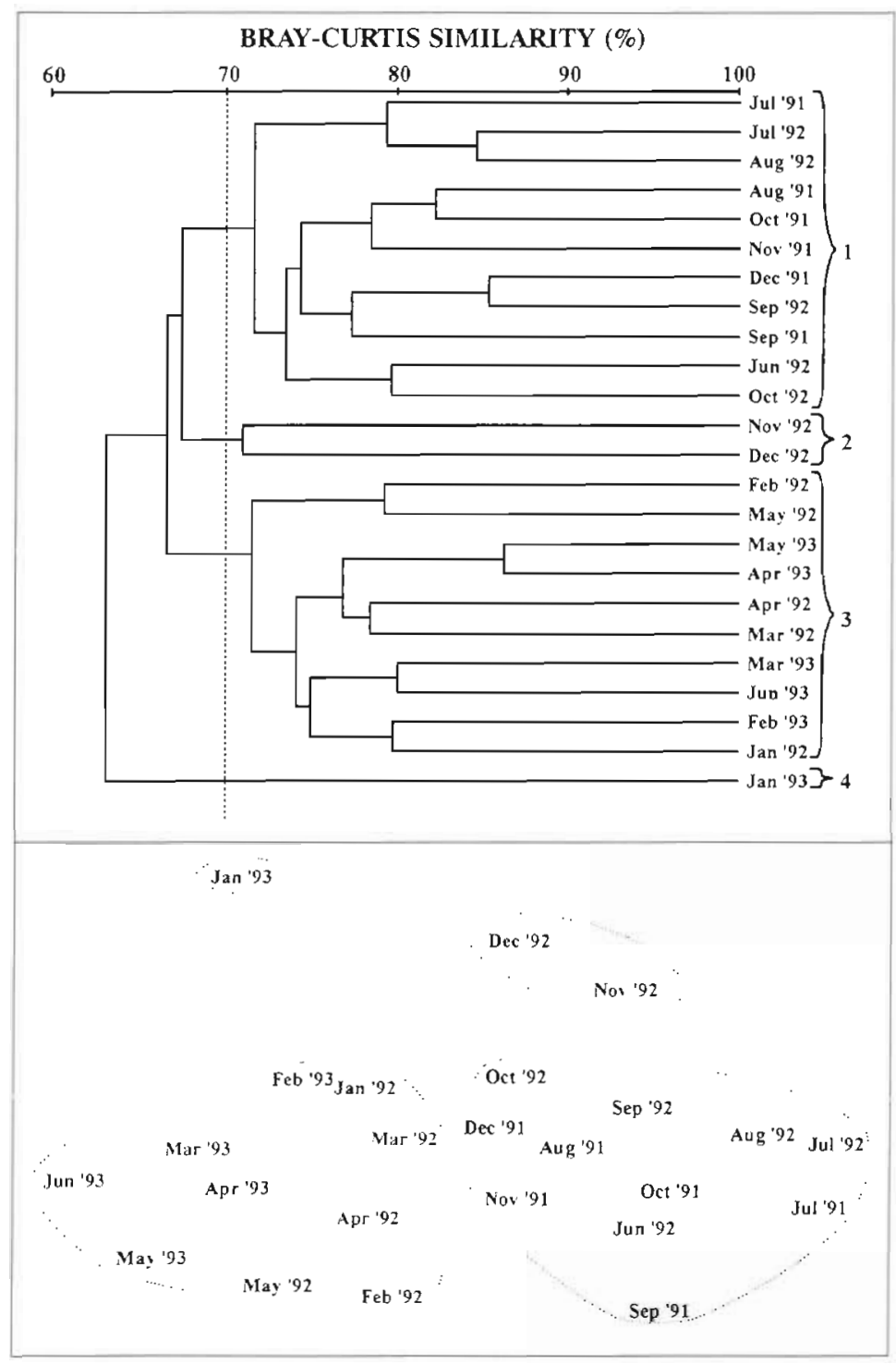

Fig. 4. Dendrogram and MDS ordination plot of density data from monthly seine net hauls made in the surf zone of False Bay, between July 1991 and June 1993. Groups of species delineated at the $70 \%$ level in the dendrogram are circled in the ordination plot. Stress for the MDS ordination $=0.20$ declined by 32 and $36 \%$ respectively. Declines in the abundance of the top 2 species (Atherina breviceps, Liza richardsonil) were primarily responsible for this reduction (nearly $50 \%$ for the former) but no change was evident in the relative ranks occupied by the top 3 species. However, important changes were evident in the relative ranking and abundance of some other important species. Many of the summer migrants (e.g. Diplodus sargus, Heteromycterus capensis and Pomatomus saltatrix) increased in abundance and relative ranking from the first to the second year, whereas most winter migrants (e.g. Liza tricuspidens, Liza dumerilii, Gilchristella aestuaria), decreased over the same period.

Sampling equipment and methodology used by Bennett (1989) to sample the fish assemblage at Fishoek Beach (also in False Bay) during 1980-81 were similar to those employed here, and it is interesting to note that although the overall composition of the catches was relatively similar, a considerable change was evident in at least 1 species. Pomadasys olivaceum, the second most abundant species recorded by Bennett (1989), was completely absent from the catches made here. It is possible that we simply failed to catch this species, but this is unlikely, as many of the sites sampled during this survey were situated in close proximity to Bennett's (1989) site, and no species captured at any of the 11 sites sampled during this survey displayed such high site specificity. It is more likely that variations in recruitment success, brought about by large-scale changes in climatic and hydrological factors, were responsible for these changes, as Ross et al. (1987) and other authors (e.g. Ziljstra \& Witte 1985, Bergman et al. 1988, Pihl 1990) have suggested.

Seasonal changes in abundance are considered by many authors (e.g. Gunter 1958, McFarland 1963, Ross et al. 1987) to be the primary characteristics of surf zone fish assemblages. Seasonality is clearly of considerable importance, as almost all studies of sufficient duration have demonstrated the existence of seasonal fluctuations in abundance and number of species in the surf (Warfel \& Merriman 1944, Gunter 1945, 1958, McFarland 1963, Anderson et al. 1977. Lasiak 1984 b - fine mesh study only, Peters \& Nelson 1987, Wright 1988, 1989, Gibson et al. 1993, Lamberth et al. 1995), in abundance only (Modde \& Ross 1981, McMichae] \& Ross 1987, Ross et al, 1987, Whitfield 1989), or at 


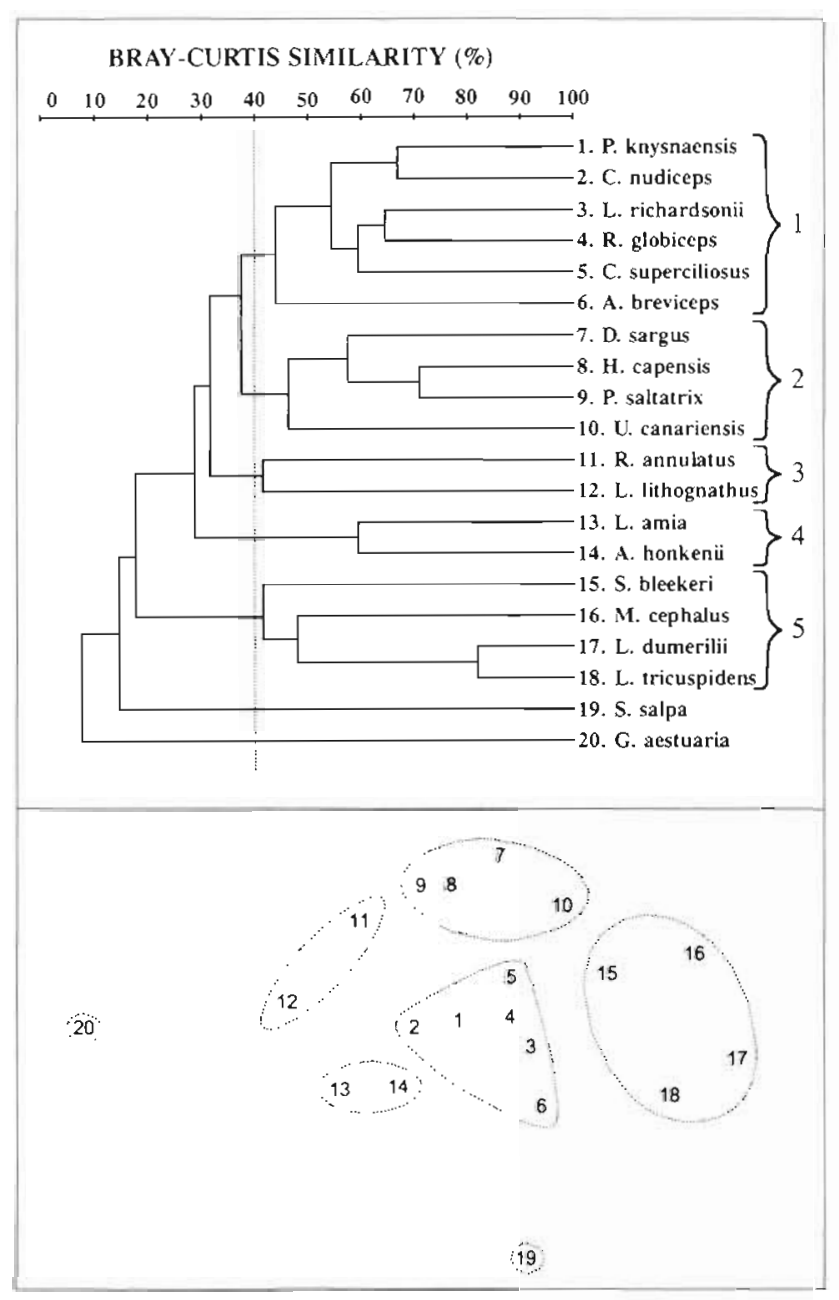

Fig. 5. Dendrogram and MDS ordination plot showing similarities between species based on their occurrence in the 24 sampling months. Groups of species delineated at the $40 \%$ level in the dendrogram are circled in the ordination plot. Stress for the MDS ordination $=0.17$

least in the number of species present (Senta \& Kinoshita 1985, Bennett 1989). Although he provided no evidence to substantiate his conclusion, Bennett (1989) suggested that the differences in the strengths of seasonal cycles reported in the literature for surf zone fishes merely reflected the magnitude of seasonal variations in physical factors (water temperature being the most important), and are thus governed by latitude.

Typically, it appears that in areas where the seasonal variation in water temperature is considerable $\left(>20^{\circ} \mathrm{C}\right)$, such as beaches in the Gulf of Mexico, on the Atlantic coast of the United States and in the Persian Gulf (Warfel \& Merriman 1944, Gunter 1945, 1958, McFarland 1963. Schaefer 1967, Anderson et al. 1977. Wright 1988,1989 ), seasonal fluctuations are very pronounced. However, seasonal fluctuations in fish com- munities frequenting sandy beaches in northern Europe, where water temperatures do not vary much, but are very low $\left(<8^{\circ} \mathrm{C}\right)$ for much of the year, are arguably the most pronounced of all. These communities are made up of almost entirely of flatfish species, comprising primarily transient juveniles, that inhabit inshore sandy beach areas for only a few months each year (Macer 1967, Edwards \& Steele 1968, Gibson 1973, Lockwood 1974, Kuipers 1977, Poxton et al. 1982, Poxton \& Nasir 1985, Pihl \& van der Veer 1992, Gibson et al. 1993). Immigration of larvae and juveniles of most species into these nursery grounds is highly synchronous and takes place over a couple of months (April-June) at the beginning of summer. After peaking during this period, numbers decline steadily as a result of natural mortality (due mainly to predation) until autumn (September/October) when numbers drop suddenly as practically all the survivors move into deeper waters offshore. Similarly, researchers working on Gulf and Atlantic coast beaches in the United States have noted that fish are either completely absent or very rare in the surf during the coldest winter months (Warfel \& Merriman 1944, Gunter 1958, McFarland 1963). Typically, however, this occurs for only 1 or 2 months of each year, when temperatures reach their lowest values. In contrast to this, in areas in which temperatures do not drop particularly low $\left(\geq 10^{\circ} \mathrm{C}\right)$, such as California and Spain, seasonal variations in the abundance, biomass and community structure of fish communities frequenting sandy beaches are usually weak or ill defined (Allen \& De Martini 1983, Reina-Hervas \& Serrano 1987)

Of the 7 physical variables recorded during this study, only surf zone water temperature and (to a lesser extent) wind direction showed clear seasonal variations. Water temperature, which ranged from 11 to $22^{\circ} \mathrm{C}$, peaked during midsummer and was significantly greater during spring, summer and autumn than during winter. Wind direction was predominantly southerly to southeasterly, punctuated by winds with a northerly component more frequently during winter than the other seasons. Mean turbidity appeared to be seasonally greater during winter in the first year, but this pattern was not matched by data from the second year. Although neither the total number nor the overall density of fish in False Bay fluctuated seasonally, seasonal patterns were evident in the total number and density of juvenile fish in the surf zone, and to a lesser extent in the species richness and the total number of fish species present in the catches. Peaks in these variables did not necessarily coincide exactly in both years, but all reached their greatest magnitude during summer and autumn (December-May). Cluster and MDS analysis separated the monthly samples roughly into seasonal components (summer; autumn and win- 
Table 2. Results of the BLOENV analysis of the influence of 9 environmental parameters on surf zone fish community structure at 11 sites in False Bay Spearman rank correlation coefficients $\left(\rho_{w}\right)$ are included for each combination of variables selected by the model

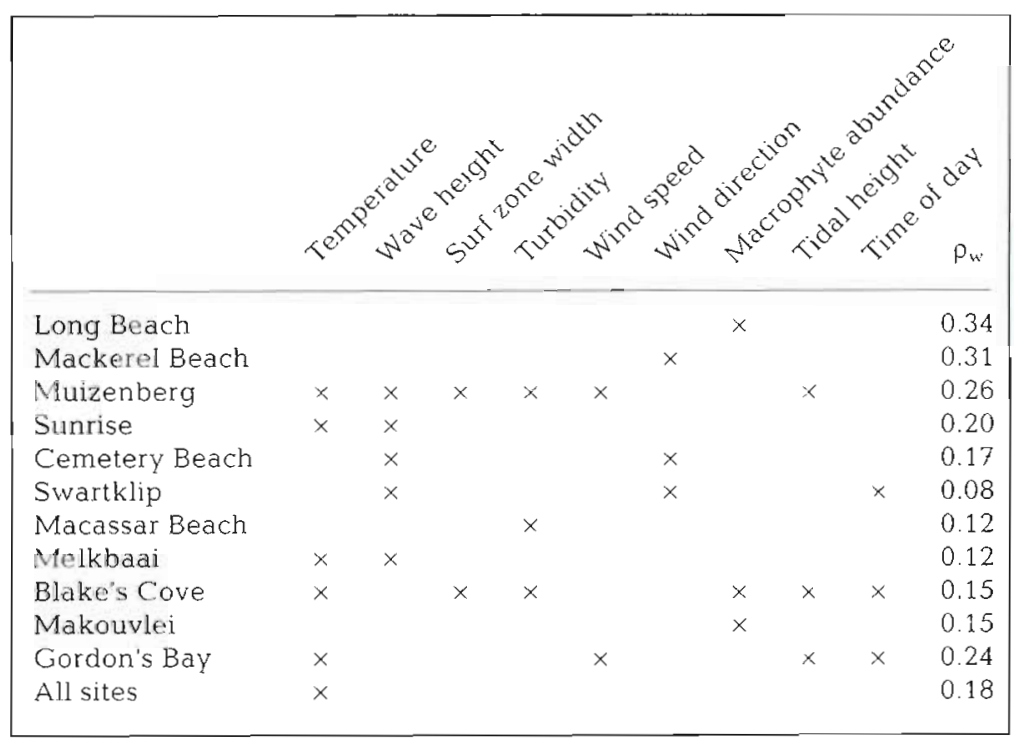

group of species (most abundant in the surf during summer and autumn) is composed of juveniles that recruit directly into the surf zone during the summer months after being spawned in spring. The second group (most abundant in the surf during autumn and early winter) is composed of post-estuarine juveniles that enter the surf as the first rains of autumn breach the mouths of the southwestern Cape estuaries in which these fish reside over the summer months. Most of these recruits do not remain in the surf for long and have been classified in this study as seasonal migrants (e.g. Lichia amia, Pomatomus saltatrix, Liza dumerilii, Liza tricuspidens), while others (e.g. Rhabdosargus globiceps) remain in the surf for most of the year, and have therefore been classified as resident species. Gilchristella aestuaria was the only species found to be more abundant during winter than any other season. This species, clas-

ter; spring), suggesting that surf zone fish community structure also fluctuates seasonally in this area.

Abundance of juvenile fish and species richness of the whole assemblage were greatest in a broad period extending from midsummer right through to the beginning of winter. This prolonged peak in abundance may be attributed to 2 overlapping waves of juveniles that recruited during this period (Clark unpubl.). The first

Table 3. Results of the stepwise multiple regression analysis of the influence of 9 envronmental parameters on surf zone fish abundance at 11 sites in False Bay. Correlation coefficients $\left(r^{2}\right.$ adj $)$ are included for each combination of variables selected by the model

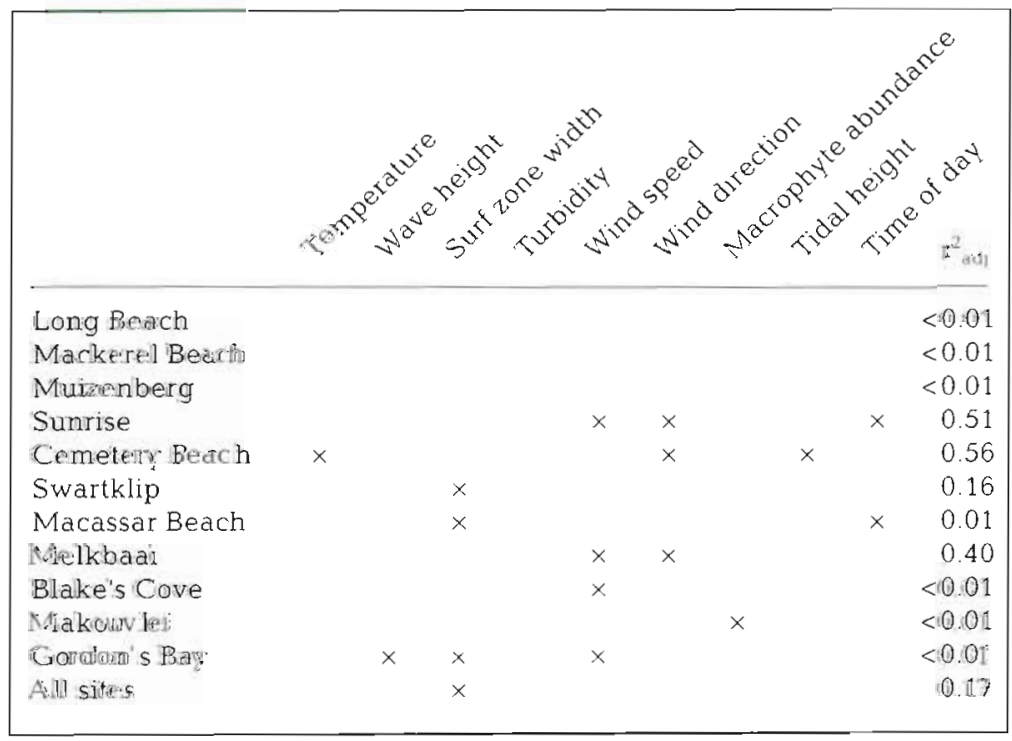
sified as an estuarine resident by Wallace et al. (1984), migrates to the heads of estuaries at the onset of the rainy season (Winter 1979), and is probably only flushed into the surf after a considerable amount of rain has fallen.

These results are consistent with those obtained in other South African studies. Bennett (1989) noted that weak seasonal fluctuations were evident in the number of species present and in the community structure of the surf zone fish assemblage at Fishoek Beach, False Bay. Seine net hauls made by Bennett (1989) yielded the greatest number of species (9 or 10 ) during the summer months and the lowest (4 or 5) during winter. Multivariate analyses separated Bennett's catches into 'spring', 'summer' and 'autumn and winter' components. Lamberth et al. (1995) found that variations in commercial beach-seine net catches in False Bay are strongly seasonal, with most fish (93\%) being caught between late spring and early autumn. However, it is unknown how much this reflected the abundance of fish in the surf and how much was a function of variations in fishing effort. Lasiak (1984b) found that no seasonal trends were discernible in either the overall abundance or species diversity of fish in coarse-mesh beach-seine hauls made in the surf at King's Beach, in Algoa Bay. However, she did find that diversity 
and number of species in the fine mesh catches made in the same area were both greater during summer than winter. Water temperatures range from 11 to $26^{\circ} \mathrm{C}$ in this area.

Little correspondence was evident between groups of species identified on the basis of seasonal variation in their abundance, and those identified on the basis of spatial variations in occurrence and abundance (Clark et al. 1996). Migrant species most abundant during autumn and early winter (Group 5; Fig. 5) were all found exclusively at sites in the northeastern corner of the Bay. This supports the notion of Clark et al. (1996) that, shortly after being flushed from estuaries, these estuarine dependent species (sensu Wallace et al. 1984) are attracted to and briefly congregate in the estuarine-like conditions that prevail in this part of the Bay. No other obvious similarities between spatially and temporally separated groups of species were evident.

Despite the application of some sophisticated multivariate techniques to data collected during this survey, the precise factors that control variations in fish abundance and community structure remain obscure. Although certain variables (e.g. water temperature, wave height, wind speed and direction) were implicated more frequently than others, every single one of the environmental variables used in this analysis was incorporated into models describing fluctuations in abundance or community structure in at least 1 of the 11 sites. Coefficients of determination $\left(\mathrm{r}^{2}{ }_{\text {add }}\right.$. values $)$ and rank correlation coefficients $\left(\rho_{w}\right)$ were, in most cases, low or not significant. This apparent unpredictability is probably a function of a number of interacting influences. Differences in the physical attributes of different sites have a profound influence on the composition of surf zone fish communities (Clark et al. 1996), which in turn is likely to influence the response of the community to any changes in these variables. Variations in the abundance of detached macrophytes, identified by Robertson \& Lenanton (1984) as the primary determinant of fish abundance, have a profound influence on fish community structure at Long Beach (Site 1), for example, but not at any of the other sites. The protection this material affords to benthic species at this site is important, as it is the only cover available in the exceptionally clear and calm waters prevalent there. The influence of wind (speed and/or direction) on abundance was strongly evident at some sites, and wind may, as Lasiak (1982) suggested, be one of the primary abiotic variable at some sites, as it has the ability to influence wave action, turbidity and localized water temperature. All biotic and environmental data were collected concurrently, and thus the influences of abiotic factors acting prior to sampling or the duration over which these variables were active were automati- cally excluded. Lasiak (1984b), for example, found that the wind speed averaged over the preceding 12 to $48 \mathrm{~h}$ had a greater influence on fish abundance than that recorded at the time of sampling, or averaged over the whole month. Also, as suggested by Clark et al. (1996). the influences of many of the abiotic factors measured are probably controlled or at least strongly moderated by others, while some (wave height and surf zone width for example) are collinear with each other, or with some variables that were not even measured. Shoaling behaviour exhibited by many species results in a patchy distribution of these individuals in the surf (Lasiak 1982, Ross et al. 1987, Gibson et al. 1993), which means that all hauls made do not necessarily represent the true abundance of fish in the surf. Thus, the interaction of these factors and the influence of variations in netting efficiency (Hunter \& Wisby 1964, Lyons 1986, Pierce et al. 1990) are likely to make longterm variability highly unpredictable and difficult to explain. However, when these multivariate techniques were applied to data from all sites combined, we found that variations in overall community structure could best be attributed to water temperature alone, which does suggest that this may be the overriding factor, within which all the other variables interact.

\section{CONCLUSIONS}

Results of this study suggest that, although temporal variations in surf zone fish assemblages are no greater than those evident over spatial scales (see Clark et al. 1996), these variations are far less predictable. Variations in point abundance appear to be least predictable of all, whereas variations in the overall structure of surf zone fish assemblages, particularly when averaged over large spatial scales, are more consistent and predictable. Long-term variations appear to be predominantly seasonal in nature and correlated with the breeding cycles of most fishes in temperate and high latitudes. Seasonal variation in water temperature appears to be the primary driving mechanism, but it is probably not the magnitude of the variation in water temperature per se that is important, but rather the lower limits there of that determine the strength of seasonal cycles in fish abundance in surf zone environments. The turbulence that characterises the surf zone environment is likely to make it an energetically expensive habitat for fish, and thus the benefits it provides in terms of cover are probably outweighed by foraging and maintenance costs for most species, when water temperatures drop below a certain level. Nevertheless, even in areas where seasonal variations in temperature are small, these results suggest that seasonal fluctuations still predominate. Thus, the spawn- 
ing periods of surf zone fish are usually timed in order to allow both transient and resident $0+$ juveniles to maximise initial growth rates while making full use of the cover provided by the surf zone waters

Acknowledgements. We thank all staff and students of the Zoology Department at the University of Cape Town who helped with the nettung surveys and with the processing of the data We also thank Prof. C. L. Griffiths and all those who commented on earlier drafts of this manuscript. This work was funded by the South African Nature foundation (aftiliated to the World Wildlife Fund for Nature) and the Sea Fishery Fund, the latter through a contract with the Sea Fishery Research Institute, South Afnca.

\section{LITERATURE CITED}

Allen LG, De Martini EE (1983) Temporal and spatial patterns of nearshore distribution and abundance of the pelagic fishes off San Onofre-Oceanside, California. Fish Bull 81: $569 ; 866$

Anderson WD Jr, Dias JK, Dias RK, Cupka DM, Chamberlain N.t (1977) The macrofauna of the surf zone off Folly Beach, South Carolina. NOAA Tech Rep NMFS SSRF-704

Bennett BA (1989) Fish community of a moderately exposed beach on the southwestern Cape coast of South Africa and an assessment of this habitat as a nursery for juvenile fish. Estuar coast Shelf Sci 28:293-305

Bergman M.JM, van der Vuror HW, Ziljstra JJ (1988) Plaice nurseries: effects of recruitment. Proc 17 th EBSA Symp Fish in Estuaries. J I itil Biol 33 (Suppl A):210-218

Blaber SJM, Blaber TG (1980) Factors affecting the distribution and abundance of juvenile estuarme and inshore fish. J Fish Biol 17:143-162

Burrows MT, Gibson RN, Robb L, Comely CA (1994) Temporal patterns of movement in juvenile flatfishes and their predators: underwater television observations. J exp mar Biol Erol 177:251-268

Clark BM, Bennett BA, Lamberth SJ (1996) Factors affecting spatial variability in seine net catches of fish in the surf zone of False Bay, South Africa. Mar Ecol Prog Ser 131. $17-34$

Creutzenberg F, Eltink ATGW, van Noort GJ (1978) The migration of plaice larvae Pleuronectes platessa into the western Wadden Sea. In: McLusky DS, Berry AJ (eds) Physiology and behaviour of marine organisms. Proc. 12 th Eur Mar Biol Symp. Pergamon Press, Oxford, p 243-252

Edwards R, Steele JH (1968) The ecology of O-group plaice and common dabs at Loch Ewe. I. Population anci food. J exp mar Biol Ecol 2:215-238

Gibson RN (1973) The intertidal movements and distribution of young fish on a sandy beach with special reference to the plaice (Pleuronectes platessa L.). J exp mar Biol Ecol 12:79-102

Gibson RN, Ansell AD, Robb L (1993) Seasonal and annual variations in abundance and species composition of fish and macrocrustacean communities on a Scottish sandy beach. Mar Ecol Prog Ser 98:89-105

Gunter $G$ (1945). Studies on the marine tishes of Texas. Publ Inst mar Sci Univ Texas 1:1-190

Gunter G (1958) Populations studies of the shallow water fishes of an outer beach in southern Texas. Publ Inst mar Scl Univ Texas 5: 186-193
Hunter JR, Wisby WJ (1964) Net avoidance behaviour of carp and other species of fish. J Fish Res Bd Can 21:613-633

Jones A (1973) The ecology of young turbot, Scophthalmus maximus (L.), at Borth, Cardiganshire, Wales. J Fish Biol 5: $367-383$

Kuipers BR (1977) On the ecology of juvenile plaice on a tidal flat in the Wadden Sea. Neth J Sea Res 11:56-91

Lamberth SJ, Bennett BA, Clark BM (1995) Seasonality and other faclors influencing beach-seine catches in False Bay with an assessment of closed periods as a management option. S Afr J mar Sci 15:157-167

Lasiak TA (1982) Structural and functional aspects of the surf zone fish community in the eastern Cape. PhD thesis, University of Port Elizabeth

Lasiak TA (1984a) Structural aspects of the surf-zone fish assemblage at King's Beach, Algoa Bay, South Africa: short term fluctuations. Estuar coast Shelf Sci 18: $347-360$

Lasiak TA (1984b) Structural aspects of the surf-zone fish assemblage at King's Beach, Algoa Bay, South Africa: long term fluctuations. Estuar coast Shelf Sci 18:459-483

Lockwood SJ (1974) The settlement, distribution and movements of 0-group plaice Pleuronectes platessa (L.) in Filey Bay, Yorkshire. J Fish Biol 6:465-477

Lyons J (1986) Capture efficiency of a beach-seine for seven freshwater fishes in a north-temperate lake. $N$ Am J Fish Manage 6:288-289

Macer CT (1967) The food web in Red Wharf Bay (North Wales) with particular reference to young piaice (Pleuronectes platessa]. Helgoländer wiss Meeresunters 15 $560-573$

Margalef R (1958) Information theory in ecology. Gen Syst $3: 36-71$

McFarland WN (1963) Seasonal change in the number and biomass of fishes from the surf at Mustang Island. Texas. Publ Inst mar Sci Univ Texas 9:91-105

McMichael RH Jr, Ross ST (1987) The relative abundance and feeding habits of kingfish (Scianidae: Menticirrhus) in a Gulf of Mexico surf zone. NE Gulf Sci 9:109-123

Merriman D (1947) Notes on the midsummer ichthyofauna of a Connecticut beach at different tide levels. Copeia 1947: $281-286$

Modde T, Ross ST (1981) Seasonality of fishes occupying a surf zone habitat in the northern Gulf of Mexico. Fish Bull US 78:911-922

Peters DJ, Nelson WG (1987) The seasonality and spatial patterns of juvenile surf zone fishes of the Florida east coast. Fla Sci 50:85-99

Pielou EC (1969) The measurement of diversity in different types of biological collections. J theor Biol 13:131-144

Pierce CL, Rasmussen JB, Leggett WC (1990) Sampling littoral fish with a seine: corrections for variable capture eff $f_{2}$ ciency. Can J Fish Aquat Sci 47:1004-1010

Pihl L (1990) Year class strength regulation in plaice (Pleuronectes platessa L. I on the Swedish west coast. Hydrobiologia 195:79-88

Pihl L, van der Veer HW (1992) Importance of exposure and habitat structure for the population density of 0-group plaice, Pleuronectes platessa L., in coastal nursery areas. Neth J Sea Res 29:145-152

Poxton MG, Eleftheriou A, McIntyre AD (1982) The population dynamics of 0-group flatfish on nursery grounds in the Clyde Sea area. Estuar coast Shelf Sci 14:265-282

Poxton MG, Nasir NA (1985) The distribution and population dynamics of 0-group plaice (Pleuronectes platessa L.) on nursery grounds in the Firth of Forth. Estuar coast Shelf Sci 21:845-857 
Reina-Hervas JA, Serrano P (1987) Structural and seasunal variations of inshore fish populations in Malaga Bay, southeastern Spain. Mar Biol 95:501-508

Riley JD, Corlett J (1966) The numbers of 0-group plarce in Port Erin Bay 1964-66. Rep Mar Biol Sta Port Erin 78: $51-56$

Robertson Al, Lenanton RCJ (1984) Fish community structure and food chain dynamics in the surf-zone of sandy beaches: the role of aquatic macrophyte detritus. J exp mar Biol Ecol 84:265-283

Ross ST, McMichael RH, Ruple DL (1987) Seasonal and diel variation in the standing crop of fishes and macroinvertebrates from a Gulf of Mexico surf-zone. Estuar coast Shelf Sci 25:391-412

Schaefer RH (1967) Species composition, size and seasonal abundance of fish in the surf waters of Long Island. NY Fish Game J 1:1-46

Senta T, Kinoshita I (1985) Larval and juvenile fishes occurring in surf zones in western Japan. Trans Am Fish Soc $114: 609-618$

van der Veer HW, Bergman MJN (1987) Predation by crustaceans on a newly settled 0-group plaice Pleuronectes platessa population in the western Wadden Sea. Mar Ecol Prog Ser 35:203-215

Wallace JH, Kok HM, Beckley LE, Bennett BA, Blaber SJM,

This article was submitted to the editor
Whitfield AK (1984) South African estuaries and their importance to fishes. S A.f J Sci 80:203-207

Warfel HE, Merriman D (1944) Studies on the marme resources of southern New England. 1. An analysis of the fish populations of the shore zone. Bull Bingham Oceanogr Coll 9:1-91

Whitfield AK (1989) Ichthyoplankton in a southern African surf zone: nursery area for the postlarvae of estuarine associated fish species? Estuar coast Shelf Scl 29:533-547

Winter PED (1979) Studies on the distribution, seasonal abundance and diversity of the Swartkops estuary ichthyofauna. MSc thesis, University of Port Elizabeth

Wright JM (1988) Seasonal and spatial differences in the fish assemblage of the non-estuarine Sulaibikhat Bay, Kuwait. Mar Biol 100:13-20

Wright JM (1989) Diel variation and seasonal consistency in the fish assemblage of the non-estuarine Sulaibikhat Bay, Kuwait. Mar Biol 102:135-142

Zar JH (1984) Biostatistical analysis. Prentice-Hall, Englewood Cliffs, NJ

Ziljstra JJ, Dapper R, Witte JIJ (1982) Settlement, growth and mortality of post-larval plaice (Pleuronectes platessa) in the western Wadden Sea. Neth J Sea Res 15:250-272

Ziljstra JJ, Witte JIJ (1985) On the recruitment of 0-group plaice in the North Sea. Neth J Zool 35:360-376

Manuscript first received: February 8, 1995

Revised version accepted: July 28, 1995 